\title{
Hermetic Seal Device
}

National Cancer Institute

\section{Source}

National Cancer Institute. Hermetic Seal Device. NCI Thesaurus. Code C50302.

A seal designed to be airtight. 